\title{
THE IMPACT OF COVID-19 ON SUPPLY CHAINS OF ALL-INCLUSIVE HOTELS
}

\author{
Salih TELLIOGLU* \\ Alanya Aladdin Keykubat University, Tourism and Hotel Management Program, Alanya, Turkey, e-mail: slhtellioglu@ gmail.com
}

Citation: Tellioglu, S. (2021). THE IMPACT OF COVID-19 ON SUPPLY CHAINS OF ALL-INCLUSIVE HOTELS. GeoJournal

of Tourism and Geosites, 35(2), 464-470. https://doi.org/10.30892/gtg.35226-673

\begin{abstract}
The restrictions that started with the Covid-19 outbreak have dramatically affected global supply chains. These issues also were reflected in the operations of many companies in different sectors. This study aims to investigate the impact of COVID-19 outbreak on the supply chain of all-inclusive accommodation companies. To that end, a semi-structured interview questionnaire is used to interview the purchasing directors of twelve different hotels. The study concludes that companies did not face significant challenges, while supplying local food products, but had a hard time, when it came to finding imported food products. Accommodation companies also had issues in certain periods in terms of the supply of hygiene products, especially such as glo ves, masks and disinfectants. Moreover, these products have been influential in the supplier selection of companies.
\end{abstract}

Key words: Purchasing, Supply chain, Supplier selection, All-inclusive hotels, COVID-19

\section{INTRODUCTION}

An important revenue source for highly visited countries and a key player in international trade, tourism is in a constant state of growth (UNWTO, 2019). The tourism industry has varying positive effects on countries of inbound and outbound tourists; at the same time, it is known as one of the industries that is highly affected by negative situations due to its delicate nature, such as terrorist attacks, political conflicts, wars, natural disasters and outbreaks (Çıtak and Çalış, 2020: 111).

Having started in the city of Wuhan in China and later spread across the world, COVID-19 outbreak brought along many negatives, such as the cancellation of reservations, the limitation decisions of countries of outbound tourists and as a result, the closing of touristic companies, severely affecting the countries, which are heavily visited by tourists. As a country that went through a number of crises, especially in the recent years, Turkish tourism industry had to face COVID-19 outbreak, without becoming entirely free of the effects of said crises, and accordingly lost tourists with a $72.5 \%$ rate compared to the same period of the last year as of the month of October (KTB, 2020). Additionally, this process also had negative impacts on the countries of outbound tourists, in relation with the positive sociological effects of such visits on tourists (Demirbulat, 2012: 53).

COVID-19 outbreak affected myriad companies and institutions, as well as financial markets and the global economy, causing an extremely rare crisis (Nicola et al., 2020: 187). Significant malfunctions occurred in the supply chain, in relation with the problems arising from the restrictions during COVID-19, since individuals could not go to work, and from the changes in consumer preferences (Karlı and Tanyaş, 2020: 174; Gonzales-Torres, 2020: 1). Although companies restarted their activities gradually after the restrictions, the lack of raw materials and parts acquired from foreign countries and the spread of virus amongst employees resulted in the quarantine of some departments, slowing down or putting a stop to production (Shen et al., 2020: 96). Especially China, where the outbreak originated, affected global supply chains, for it is one of the most important suppliers in the world with respect to raw materials, semi-finished and finished products. The spread of the outbreak across the world and the issues, arising from the global supply chain, also had negative influences on local supply chains (Karl and Tanyaş, 2020: 174-180). Emerged in the production industry, supply chain piqued the interest of a number of researchers and practitioners in different industries, but not in the tourism industry (Zhang et al., 2009: 346). However, the intersecting, interdependent and fragmented structure of tourism products force firms to cooperate with many suppliers, distributors, competitors and other firms in the industry. This cooperation is viewed as the driving force of agility, flexibility and organizational performance, demonstrating the importance of the supply chain for touristic enterprises (Gonzales-Torres, 2021). Still, the particular nature of tourism and its characteristics must be taken into account, while the specific supply chain practices for the tourism industry are determined (Zhang et al., 2009: 346). This is largely due to the structure of the tourism industry, where the tourism products are manufactured and consumed in the same place (Palang and Tippayawong, 2019: 1193).

This study aims to investigate the impact of COVID-19 process on the supply chains in all-inclusive accommodation companies. Supply chain has specifically a deep impact on the costs and quality of firms that purchase large numbers of products (Zhang et al., 2009: 346). In this context, the large amount and variety of the products purchased by all-inclusive accommodation companies illustrate how important supply chain is for them. Furthermore, globalization and the rapidly changing business practices drive touristic companies to not only reduce costs, but also constantly improve product and service quality, as well as delivery performance. Due to the growth and the increasing competition in the tourism industry, accommodation companies must provide better services than their competitors and ensure customer satisfaction (Mohanty and Gahan, 2012: 319). The most important factor to provide a competitive edge to accommodation companies is customer

* Corresponding author 
satisfaction (Forozia et al., 2013: 4329). In such companies, the number of customers increase in direct proportion with customer satisfaction and the improvement in both customer satisfaction and loyalty would ensure that the company will be preferred by new customers more frequently (Taplin, 2013: 238). In this context, selection of suppliers and supply chain management become critical subjects during the process of service of especially all-inclusive accommodation companies (Vatansever and Tellioğlu, 2020: 139). That is because supply chain management contributes to financial indicators such as cost and profitability, in addition to non-financial ones such as customer satisfaction (Tigu and Calaretu, 2013: 106). The fact that the importance of supply chain in such companies and the impact of COVID-19 on the supply chain of all-inclusive accommodation companies are not studied, display the significance of this study. From this perspective, the findings from this study are hoped to contribute to the literature to a large extent. Furthermore, the findings will be guiding the directors in the tourism industry as well as other stakeholders in taking preventative measures, in the event that other crises arise in future. The research study is conducted in the Alanya district of Turkey. In addition to being one of the most important tourism destinations in Turkey, Alanya commonly hosts a large number of all-inclusive accommodation companies. Therefore, the research section of this study includes the interviews with the purchasing directors of twelve different all-inclusive hotels in Alanya via semistructured interview questionnaires. The study uses case study approach from amongst qualitative research designs.

\section{LITERATURE REVIEW}

\section{The Impact of COVID-19 on the Tourism Industry}

An unmatched crisis on a global scale, COVID-19 outbreak had extensive impact on almost all industries (Deloitte, 2020). This process affected all sectors, especially those regarding health, agriculture, food, transportation, logistics, education and tourism (Karlı and Tanyaş, 2020:180). Originated in the city of Wuhan in China, the outbreak rapidly spread throughout the globe, causing the closing of borders, cancellation of flights and the closing down of many touristic enterprises due to travel limitations, resulting in the tourism industry taking the most damage from this outbreak because of its delicate nature (KTB, 2020).

Overall, COVID-19 led to international distortions in the tourism sector and severe declines in hotel occupancy rates (Nicola et al., 2020: 188). According to the data from March 2020, occupancy rates declined in Japan (by $62 \%$ ), South Korea (by $74 \%$ ), Italy (by $75 \%$ ) and China (by $76 \%$ ) (Skift, 2020). The outbreak built a barrier before the travel and tourism expenses of individuals across a number of countries in the world, regardless of their socio-economic statuses (Aydin and Doğan, 2020: 98). Therefore, many employees in the tourism industry lost their jobs. Marriott hotel chains with 174,000 employees across the world put many of their employees on temporary leave without pay (USA Today, 2020). Accor Group, on the other hand, declared that 80 percent of its 25,000 employees in China are now working remotely from home (Skift, 2020). World Travel and Tourism Council issued a warning, stating that COVID-19 outbreak may cause 50 million workers around the world in travel and tourism industries to lose their jobs (World Economic Forum, 2020). As can be inferred from this data, no other crisis has affected the world tourism industry as much as this outbreak has (UNWTO, 2020).

One of the significant tourism destinations across the world, Turkey is also known as a country of tourism, where allinclusive accommodation companies are quite widespread. Having been affected by terrorist attacks and political factors in the country on multiple occasions and therefore lost a significant number of tourists, the Turkish tourism sector (Çelik and Karaçuka, 2017: 33) had to face the outbreak, just when it started to recover. As an important touristic destination with approximately 50 million tourists annually, Turkey, much like other tourist destinations, was severely affected by this process (KTB, 2020). Table 1 includes the illustrating number of tourists from the last three years.

Once Turkey entered into the process of normalization in the month of June, the domestic travel restrictions first and the international travel restrictions for certain countries later were removed. In order for individuals to travel freely and go on vacations, The Ministry of Culture and Tourism prepared "Safe Tourism Certification Program" with the contributions of the Ministries of Health, Transportation, Interior Affairs and Foreign Affairs, representing one of the first of its kind in the world, thanks to the cooperation of all stakeholders in the industry. Turkey's very own Safe Tourism Certification Program defines a number of precautions, suggested to be employed on a wide scale, ranging from transportation to accommodation, even including the health statuses of both hotel employees and guests for all Turkish citizens and foreign visitors, who are to spend their vacations in Turkey (TGA, 2020b). These precautions were highly praised in both national and international press (Hurriyet, 2020; Express, 2020). Thanks to these regulations, countries such as Russia, Germany and Britain, which are important for Turkish tourism, issued decisions, making sure that their citizens visit Turkey. As can be observed in Table 1, the number of tourists as of the month of July witnesses an increment in numbers, compared to past months; still, a comparison with past years also reveal severe losses with some even reaching 99 percentage rates in certain months.

\section{The Impact of COVID-19 on Supply Chains}

Supply chain encompasses the process of bringing together the raw materials, auxiliary products and production instruments to be used in the production process and the delivery of the products to end users with optimal costs and conditions (Timur, 2013: 4). Generally, put, supply chain involves the moving of goods, services and information from raw material to end user (Monzka et al., 2009: 10). It can be expressed that as the global economy gradually becomes more competitive, the firms that handle their supply chains well may become those with the most advantages in the business world (Presutti, 2003: 219).

Introduced with COVID-19 outbreak, restrictions caused many enterprises in different sectors to experience problems by affecting their global and local supply chains (Nicola et al., 2020: 187; Karlı and Tanyaş, 2020: 174; Gonzales-Torres, 2020: 1). Precautions in various countries such as lockdowns, bans on opening one's workplace and traveling restrictions to prevent the spreading of the disease reduced production and even brought it in some industries to a complete halt (Eichenbaum et al., 2020). Simultaneous cutbacks also occurred in supply, demand and logistical infrastructures during other outbreaks of SARS, 
MERS, Ebola and Swine Flu; yet none of them was as effective as this one on the global scale (Ivanov, 2020: 2). Businesses under the influence of COVID-19 experienced a number of issues in procuring raw materials and parts (Shen et al., 2020: 98). Especially since China is one of the most significant suppliers in the world with respect to raw materials, semi-finished and finished products, the impact of COVID-19 on the global supply chain was substantially felt (Karl1 and Tanyaş, 2020: 174180). Furthermore, problems in the workforce, arising from the exclusion of infected employees for some time, in addition to the problems in the supply chain, gave way to the supply of a limited number of products (Shen et al., 2020: 98).

Table 1. Number of inbound tourists visiting Turkey by years and months (KTB, 2020)

\begin{tabular}{|l|c|c|c|c|}
\hline Months & $\mathbf{2 0 1 8}$ & $\mathbf{2 0 1 9}$ & $\mathbf{2 0 2 0}$ & $\begin{array}{c}\text { Change \% } \\
\mathbf{( 2 0 1 9 - 2 0 2 0 )}\end{array}$ \\
\hline January & 1.461 .570 & 1.539 .496 & 1.787 .435 & 16,11 \\
\hline February & 1.527 .070 & 1.670 .238 & 1.733 .112 & 3,76 \\
\hline March & 2.139 .766 & 2.232 .358 & 718.097 & $-67,83$ \\
\hline April & 2.655 .561 & 3.293 .176 & 24.238 & $-99,26$ \\
\hline May & 3.678 .440 & 4.022 .254 & 29.829 & $-99,26$ \\
\hline June & 4.505 .594 & 5.318 .984 & 214.768 & $-95,96$ \\
\hline July & 5.671 .801 & 6.617 .380 & 932.927 & $-85,90$ \\
\hline August & 5.383 .332 & 6.307 .508 & 1.814 .701 & $-71,23$ \\
\hline September & 4.792 .818 & 5.426 .818 & 2.203 .482 & $-59,40$ \\
\hline October & 3755467 & 4.291 .574 & 1.742 .303 & $-59,40$ \\
\hline
\end{tabular}

Table 2. Respondent Profiles

\begin{tabular}{|c|c|c|c|c|c|}
\hline No & Age & Sex & $\begin{array}{c}\text { Marital } \\
\text { Status }\end{array}$ & $\begin{array}{c}\text { Hotel of } \\
\text { Employment }\end{array}$ & $\begin{array}{c}\text { Experience } \\
\text { (in years) }\end{array}$ \\
\hline 1 & 52 & M & Married & Five-star & 24 \\
\hline 2 & 45 & M & Single & Four-star & 10 \\
\hline 3 & 44 & M & Married & Five-star & 15 \\
\hline 4 & 47 & M & Married & Four-star & 20 \\
\hline 5 & 31 & M & Married & Four-star & 10 \\
\hline 6 & 42 & M & Married & Four-star & 17 \\
\hline 7 & 41 & M & Married & Four-star & 12 \\
\hline 8 & 41 & M & Married & Five-star & 13 \\
\hline 9 & 39 & M & Married & Five-star & 20 \\
\hline 10 & 45 & F & Single & Four-star & 18 \\
\hline 11 & 35 & M & Married & Resort & 12 \\
\hline 12 & 40 & M & Married & Five-star & 18 \\
\hline
\end{tabular}

\section{METHODOLOGY}

The purpose of this study is to identify the disruptions in the supply chains of all-inclusive hotels that kept their services ongoing during COVID-19 outbreak, as well as the changes in their selections of products and suppliers. The study adopts the case study approach from amongst qualitative research designs. Case study is a research method, which studies a current phenomenon in its own real life framework, where the boundaries between the phenomenon and the setting, in which it finds itself, are not quite clear (Yin, 1984; as cited in Y1ldırım and Şimşek, 2018: 289).

The working group for this study comprises five-star and four-star accommodation enterprises and resorts that operate in Alanya district of the city of Antalya. As of 2019, there are eighty-six five-star hotels, one hundred and four four-star hotels and five holiday villages in Alanya (ALTSO, 2019). Within the scope of the study, a semi-structured interview questionnaire was conducted with the purchasing managers of all-inclusive accommodation companies that kept is services in the summer of 2020. The number of respondents for these interviews are determined with the strategy of "theoretical saturation". According to Strauss and Corbin (1998), information acquired from the interviews must achieve theoretical saturation to reach sufficient numbers of respondents in qualitative research studies. Within the scope of this study, interviews with twelve respondents are conducted, providing data at a level of contribution for the study. Basic information of the participants is shown in Table 2. The sampling for the study, on the other hand, is selected as random sampling. According to this method, the researcher designates a random sample group from the population and selects a smaller subgroup, about which the researcher thinks to be of greatest contribution for the study (Tashakkori and Teddlie, 2010, as cited in Baltac1, 2018: 258). There is only one interview that was conducted with a female respondent due to the very few number of female purchasing directors at accommodation companies in Alanya. Criteria for the selection of respondents for this study included acting as a purchasing director at a company that was active during COVID-19 and a minimum of ten years' experience in the tourism industry. The designated authority and experience of the respondents ensured to acquire findings in a larger scope. In addition to the vast experience of the individuals in the tourism industry, their posts at different hotels in different categories and their different levels of education enrich the findings, acquired within the scope of the research study. The interview questionnaire includes, first and foremost, questions about the interviewee and the company of employment. The following questions concern the product procurement, supplier selection and the designation of critical products for these companies during COVID-19 outbreak. Interviews with the respondents are carried out vis-à-vis within the scope of the research and respondents' consent for the recording of interviews are obtained. A total of twelve questions were asked to the respondents and the interviews took between 15 and 35 minutes in duration. Conducted within the scope of the research study, all interviews were recorded in Turkish and later transcribed.

This study uses descriptive analysis from amongst qualitative research methods. A descriptive analysis reveals what the collected data says about the research problem and what outcomes are inferred from said data (Y1ldırım and Şimşek, 2018). On the other hand, Wolcott (1994) suggests three main methods regarding descriptive analysis. According to one of these methods, the opinions of the respondents of the study are to be relayed to the readers as direct quotes. This would preserve the original state of the acquired data and the results would therefore be in close proximity of each other.

\section{FINDINGS}

This section scrutinizes the findings of the study in different categories as per the three aspects of the study:

Findings concerning the difficulty of availability of some products

Findings concerning supplier preferences

Findings concerning critical product preferences

Thus, categories are formed under these three different aspects. 


\section{Findings concerning the Difficulty of Availability of Some Products}

Respondents are asked questions regarding the products with which they had difficulty in procuring, in this section of the study. According to the findings as per the responses, sub-headings are formed as below.

\section{Issues in finding highly demanded products}

Due to their high purchasing volumes, all-inclusive accommodation companies had challenges in finding large amounts of certain products. Relevant comments from the respondents are as follows:

"When we first opened the hotel, we had a really hard time finding sanitizers, masks, gloves and visors, which are products that were used most frequently during this process; we even had to purchase them with really high prices. But as time went on, we started having less problems in procuring these products. Also, their prices declined over time" $K 3$

"We opened earlier than other hotels; still, it was a bit hard for us to find masks and gloves at the time. I guess there was much demand for such products from abroad as well" $K 5$

"We did not have many problems in food products. The only thing was yeast; it was really hard to find. Still, we had issues in finding large amounts of hygiene products. Sometimes it was masks, sometimes gloves and sometimes cologne that was hard to find "K8

Consumers displayed excessive demands for some products in supermarkets, while there were issues in production, leading to the lack of production of certain goods, which caused problems in the supply of certain products. One of the respondents commented on it as below: "For example, there is one product that would never occur to you - yeast. It was very difficult to find. It was easy to understand why sanitizers, cologne, masks and gloves were hard to find, but we just could not figure out why yeast was so rare. Then we found out that people started making bread at home due to the lockdown and restrictions and yeast became highly demanded. That was why it was difficult for us to find it" K12

\section{Declining prices due to declining supply for some products}

Even though some highly demanded products were difficult to acquire, some wholesale products did not meet expected sales numbers, for some of the companies were closed, which was why vendors faced challenges in selling these products. The respondent comments on it can be found below:

"Hotels usually use shock-frozen meat products and since hotels were closed, these firms were stuck with substantial surplus. We were able to find these products in large amounts and they had more reasonable prices than recent years. Especially chicken and turkey prices declined" $K 2$

"Shock-frozen turkey and chicken vendors had a lot of products in their warehouses. As their expiration dates approached, these firms had to sell their products at a loss. The prices for such products were very reasonable"K4

\section{Issues in finding imported products}

Challenges in the global supply chain caused problems in especially the procurement of imported products. The respondent comments on it can be found below:

"We could not procure the spare parts of the imported floor cleaning machine we use inside the hotel. This has never happened before, therefore we did not have these spare parts of the machine in stock. But we will definitely keep spare parts in hand from now on. Because we had a lot of problems at the time, when that particular machine was not functioning "K5

"It was not difficult for us to find products, since not all hotels were open; but it was difficult to procure imported food products. So we used whatever imported products we could find and did not use the ones we could not"K10

\section{Findings concerning Supplier Preferences}

This section of the study includes questions concerning whether or not there are differences in the selection of suppliers during Covid-19 in comparison with past years and companies work with various suppliers. Categories, formed according to the findings derived from the answers to said questions and respondent comments are provided below.

\section{Not taking the risk of changing suppliers}

Respondents highlight that switching suppliers at such times is quite risky. The respondent comments on it are as follows:

"We did not make any changes with regards to our suppliers, because we are satisfied with the performance of the suppliers with whom we work and we have been working with the same names for years. If you change your supplier, you cannot be sure whether or not this new supplier will bring the products to you in time or they are going to be reliable. These are all risks" $K 12$

"We would not simply switch suppliers, we have been working with the same suppliers for years. Due to this stability we show, our suppliers always prioritize us. Therefore, we did not have any difficulties - even with rarer products. However, when it came to masks, we acquired them from a firm in Istanbul to buy them for a cheaper price. For the other products, we worked with the same suppliers" $K 2$

\section{Critical products driving towards various suppliers}

As per the circumstances brought along by this process, some respondents declared they switched suppliers. Their comments about it are as below:

"We mostly opted for firms in Alanya due to COVID-19. Because we had sudden product demands. But we also continued to be in business with some firms we trust in Antalya. We purchased masks from firms in Istanbul" $K 7$

"We worked with more corporate suppliers because of the outbreak; smaller suppliers had difficulties especially in procuring gloves, masks, sanitizer and visors. However, big firms were able to purchase these goods in larger volumes and keep stocks because of their strong connections and they were able to deliver them to us without huge challenges. Still, we did not work with suppliers, who do not have product certificates and do not have enough documents" KI 
Findings concerning Critical Product Preferences

This section of the study includes questions for respondents regarding what products are critical during COVID-19 and whether or not packaging structures or sizes are different in comparison with past years in order to serve under more hygienic circumstances. Categories, formed according to the findings derived from the answers to said questions and respondent comments are provided below.

\section{Certain products becoming critical due to legal obligations}

Respondents emphasized the importance of products such as masks, gloves and sanitizers during the time of COVID-19, stating that they became critical products. Respondent opinions about this topic are as below:

"When it was decided that the hotel was going to be opened, the first products we searched for were masks and gloves. You could not open your hotel without them, because it was the very first prerequisite for safe service criteria. There was extreme attention towards these products during that time, which was why we had challenges in finding them at certain times "K11

Another respondent stated that critical product preferences changed this year, compared to past years:

"Staple food products such as oil, sugar, flour and meat were very important for us before COVID-19. But after this outbreak, the most important products are now masks, gloves and sanitizers. We also used plastic and carton cups more frequently" K6

\section{Increased Demand for Disposable Products}

Respondents stated that they turned to disposable products to reduce contact between individuals and serve in a safer environment during this time. In this context, human health was paid utmost attention, while waste management became of secondary importance during the outbreak. The respondent comments are as below:

"We were not able to use disposable products before due to green star criteria, but after COVID-19, breakfast foods such as jam, honey and butter, as well as spices such as salt and black pepper, had to be used in disposable forms" K12

"We were told in audits before this period that disposable ketchup-mayonnaise, plastic cups or plastic cutlery are not to be used. However, in this period it became the exact opposite - we turned to disposable products to serve under more hygienic circumstances" $K 4$

\section{RESULTS AND DISCUSSION}

A limited number of accommodation companies started to operate in the summer of 2020 with the removal of the restrictions in Turkey, but they were forced to provide their services within the scope of the "Safe Tourism Certification Program" due to COVID-19 outbreak. While accommodation companies attempted to serve according to the criteria designated within the scope of said program, they simultaneously tried to avoid any issues in their procurement of products. But, COVID-19 outbreak has already become a crisis, affecting the supply and demand of all products (Deb and Nafi, 2020: 1491). Approached within the scope of this study, all-inclusive accommodation companies especially have to eliminate any issues in their procurements of products due to their usage in large amounts and great variety (Tellioğlu, 2020: 181). That is because a touristic product is the product of an intensively coordinated industry, comprising of various products and services brought together (Zhang et al., 2009: 347). The topic of analysis of this study is the impact of the problems, which emerged in supply chains during COVID-19 outbreak on all-inclusive accommodation companies. The findings of the study conclude that problems in the supply chain during COVID-19 affected product procurement, selection of suppliers and critical product preferences of accommodation companies that remained active during this time.

Within the scope of the "Safe Tourism Certification Program", accommodation companies became obligated to have masks at hotel entrances for both customers and employees, have all of their employees use masks, have all food and beverage employees wear gloves and bonnets and offer sanitizers at multiple points (TGA, 2020a). These products became critical for accommodation companies during the outbreak, for they could not operate without them. However, especially in the early stages of the outbreak, consumers showed intense demand towards such products in a state of panic and with the limited supply of products, their procurement became challenging (Nicola et al., 2020: 185). When they went back to their activities in June (2020), accommodation companies had difficulties in acquiring these products and had to purchase them with higher prices. Moreover, many companies resorted to finding various suppliers to specifically find said products. The challenges in supply for these companies were not limited to this issue either. Due to the problems in the global supply chain, imported food products and spare parts for particular machines were difficult to be supplied as well. The most important factor as to why there were not supply issues in many other products, on the other hand, is the closing of numerous companies during COVID19 and the low occupancy rates in others in operation, causing them to consume smaller amounts of products. Thus, the supply in a number of products did not yield any issues, for the accommodation companies consumed less than they did in previous years. This decline in demand even caused surplus in shock-frozen meat product stocks in warehouses and these vendors attempted to sell these products before their expiration dates with low price policies.

The "Safe Tourism Certification Program" recommends the use of disposable products for every product possible in order to minimize contact between persons (TGA, 2020a). However, this practice contradicts the criteria in the Environment Friendly Establishment Certification of the Ministry of Culture and Tourism (KTB, 2008). This certificate recommends avoiding the use of disposable products (T.C. Resmi Gazete, 2017). The increasing use of disposable products also causes increments in packaging wastes (Sharma et al., 2020; Zambrano-Monserrate et al., 2020). Therefore, a substantial increase in the packaging wastes of accommodation companies is expected until the outbreak comes to an end. Accommodation companies have also contributed to the increase of environmental issues in the past years (Patwary et al, 2021), but it is predicted that these effects will increase with the Covid 19 outbreak. In addition, the increase in disposable products did not 
only occur in the accommodation industry. For example, a popular coffee company started to use porcelain mugs instead of the disposable coffee cups within the scope of waste management, but due to COVID-19, the very same company had to temporarily ban the usage of reusable mugs (Zambrano-Monserrate et al., 2020). Thus, COVID-19 outbreak does not only harm human health, but also the environment by bringing along new challenges to waste management (Silva et al., 2020).

\section{Managerial Implications}

The findings of this study indicate that during COVID-19, touristic establishments experienced issues in their supply chain, had difficulties during certain periods in procuring highly demanded products, had differing preferences in terms of critical products and changed their supplier preferences in order to procure these products. Findings of this study, investigating the impact of COVID-19 on the supply chain of all-inclusive accommodation companies, may guide managers and other stakeholders in the tourism industry to face potential problems that may arise in future crises. While supply chain carries paramount importance for especially all-inclusive accommodation companies, many of them did not place sufficient attention on it. However, issues in the supply chain of some products, arising from COVID-19 outbreak, have drawn the attention of managers to it. Facing various cutbacks because of COVID-19, companies must extensively consider the addition of back-up suppliers to their supply chain, collaboration with more corporate and bigger suppliers and the adoption of smart production technologies, based on cooperation on all levels of the business. This way, the endurance and viability of the company would be improved, helping the company cope with the effects of the outbreak or any other emergencies (Shen et al., 2020: 97).

Another significant finding of this study is that COVID-19 has been as harmful for the environment as human health. The rules, designated for accommodation companies during this time, caused disposable products to be used more. In this context, these companies have to place more importance on waste management. It is assumed that once this process is over, people will not behave as they used to and they will be more careful about their hygiene, favoring disposable products above others. Therefore, companies must train their employees in waste management and make announcements to their customers too in order to raise awareness about this matter. Once COVID-19 outbreak comes to an end, supply chain stakeholders will have to identify, in order to avoid similar issues in a future crisis; what worked in supply chains during the crisis, what caused the failures and how they can build stronger supply chain partnerships. In addition, steps must be taken to reduce consumer behaviors of panic buying and stocking for similar crises in future. Studies to have a better understanding on consumer motivations in this sense and their impact on food supply chains must be conducted to lessen the effects of such behavior (Hobbs, 2020: 175).

\section{Limitations and directions for future research}

Results of this study includes limitations originating from its methodological design. The qualitative research method employed in this study does not allow us to understand the case, examined in other contexs, or draw foreseeable conclusions regarding other industries (Gonzales-Tores et al., 2021). Additionally, the research study was conducted only in the destination of Alanya and other destinations were not included within the scope of this study due to restrictions of time and budget. Analyses concerning other issues, arising from the COVID-19, for accomodation companies are recommended for future studies. For instance, increasing waste in accomodation companies represents a threat for sustainable tourism during this process of COVID19. Therefore, studies of various researches in this subject would be important for the sake of drawing attention to this issue.

\section{REFERENCES}

Aydın, B., \& Doğan, M. (2020). Yeni Koronavirüs (COVID-19) Pandemisinin Turistik Tüketici Davranışları ve Türkiye Turizmi Üzerindeki Etkilerinin Değerlendirilmesi [Evaluation of Effects of the COVID-19 Pandemic on Touristic Consumption Behavior and Tourism in Turkey]. Journal of Theory and Practice in Marketing, 6 (1), 93-115.

Baltacı, A. (2018). Nitel Araştırmalarda Örnekleme Yöntemleri ve Örnek Hacmi Sorunsalı Üzerine Kavramsal Bir İnceleme [Conceptual Review of Sampling Methods and Sample Size Problems in Qualitative Research]. Bitlis Eren University Social Science Journal, 7(1), $231-274$.

Çelik, N., \& Karaçuka, M. (2017). The Effects of Terror Attacks on Tourism Sector: An Empirical Analysis in Turkey Example. Ege Academic Review, 17(3), 313-322. https://doi.org/10.21121/eab.2017328399

Çıtak, N., \& Çalış, Y.E. (2020). Covid-19 Salginin Turizm Sektörü Üzerine Olan Finansal Etkileri [Financial Effect of COVID-19 Epidemic on Tourism Sector]. İda Academia Journal of Accounting and Public Finance, 3(2), 110-132. http://www.idaacademia.org/tr/pub/issue/56389/743528

Deb, S.K., \& Nafi, S.M. (2020). Impact Of Covid-19 Pandemic On Tourısm: Recovery Proposal For Future Tourısm. GeoJournal of Tourism and Geosites, 33(4spl), 1486-1492. https://doi.org/10.30892/gtg.334spl06-597

Deloitte (2020). Re-supply chain after COVID-19. (Accessed on 17.10.2020). https://www2.deloitte.com/content/dam/Deloitte/tr/ Documents/consulting/COVID-19-sonrasi-yeniden-tedarik-zinciri.pdf

Demirbulat, Ö.G. (2012). Turizmin Sosyal Ve Kültürel Etkilerinin Turist Rehberleri Tarafindan Algilanmasi Üzerine Bir Araştirma: Trabzon İli Örneği [A search about the perception of social and cultural impacts of tourism by tourist guides: A sample in Trabzon]. Journal of Commerce \& Tourism Education Faculty, 2012 (1), 53-75. https://dergipark.org.tr/en/download/article-file/842577

Eichenbaum, M.S., Rebelo, S., \& Trabandt, M. (2020). The Macroeconomics of Epidemics, 2020. Northwestern University, Chicago, USA.

Forozia, A., Zadeh, M.S., \& Gilani, M.H.N. (2013). Customer Satisfaction in Hospitality Industry: Middle East Tourists at 3star Hotels in Malaysia. Research Journal of Applied Sciences, Engineering and Technology, 5(17): 4329-4335. https://doi.org/10.19026/RJASET.5.4425

Gonzales-Torres, T., Rodriguez-Sanchez, J.L., \& Pelechano-Barahona, E. (2021). Managing relationships in the Tourism Supply Chain to overcome epidemic outbreaks: The case of COVID-19 and the hospitality industry in Spain. International Journal of Hospitality Management, 92 (2021). https://doi.org/10.1016/j.ijhm.2020.102733

Hobbs, J.E. (2020). Food supply chains during the COVID-19 pandemic. Cand J Agr Econ., 2020 (68), 171-176. https://doi.org/10.1111/cjag.12237

Ivanov, D. (2020). Predicting the Impacts of Epidemic Outbreaks on Global Supply Chains: A Simulation-Based Analysis on the Coronavirus Outbreak (COVID-19/SARS-CoV-2) Case. Transportation Research Part E: Logistics and Transportation Review, 136, 101922. https://doi.org/10.1016/j.tre.2020.101922

Karlı, H., \& Tanyaş, M. (2020). Pandemi Durumunda Tedarik Zinciri Risk Yönetimine İlişkin Öneriler [Suggestions for Supply Chain Risk Management in the Case of Pandemic]. İstanbul Ticaret Üniversitesi Sosyal Bilimler Dergisi, 19 (37), 174-190. 
Mohanty, M.K., \& Gahan, P. (2012). Buyer Supplier Relationship in Manufacturing Industry - Findings from Indian Manufacturing Sector. Business Intelligence Journal, 5(2), 319-333.

Monzka, R., Handfield, R., Giunipero, L., \& Petterson, J. (2009). Purhasing and Supply Chain Management (Fourth Edition), SouthWestern Cengage Learning, Ohio, USA.

Nicola, M., Alsafi, Z., Sohrabi, C., Kerwan, A., Al-Jabir, A., Iosifidis, C., Agha, M., \& Agha, R. (2020). The socio-economic implications of the coronavirus pandemic (COVID-19): A review. International Journal of Surgery, 78 (2020), 185-193. https://doi.org/10.1016/j.ijsu.2020.04.018

Palang, D., \& Tippayawong, K.Y. (2019). Performance evaluation of tourism supply chain management: the case of Thailand. Business Process Management Journal. 25 (6), 1193-1207. https://doi.org/10.1108/BPMJ-05-2017-0124

Patwary, A.K., Omar, H., \& Tahir, S. (2021). The Impact Of Perceived Environmental Responsıbility On Tourists' Intention To Visit Green Hotel: The Mediatıng Role Of Attitude. GeoJournal of Tourism and Geosites, 34(1), 9-13. https://doi.org/10.30892/gtg.34101-612

Presutti, W.D. (2003). Supply management and e-procurement: creating value added in the supply chain. Industrial Marketing Management, 32, $219-226$.

Sharma, H.B., Vanapalli, K.J., Cheela, V.R.S., Ranjan, V.P., Jaglan, A.K., Dubey, B., \& Goel, S., Bhattacharya, J. (2020). Challenges, opportunities, and innovations for effective solid waste management during and post COVID-19 pandemic. Resources, Conservation \& Recycling, 162 (2020), 105052. https://doi.org/10.1016/j.resconrec.2020.105052

Silva, A.L.C., Prata, J.C., Walker, T.R., Campos, D., Duarte, A.C., Soares, A.M.V.M., Barcelo, D., \& Rocha-Santos, T. (2020). Rethinking and optimising plastic waste management under COVID-19 pandemic: Policy solutions based on redesign and reduction of single-use plastics and personal protective equipment. Science of the Total Environment, 742 (2020), 140565. https://doi.org/10.1016/j.scitotenv.2020.140565

Strauss, A., \& Corbin, J. (1998). Basics of Qualitative Research: Techniques and Procedures for Developing Grounded Theory. Sage publications, Thousand Oaks, USA.

Shen, W., Yang, C., \& Gao, L. (2020). Address business crisis caused by COVID-19 with collaborative intelligent manufacturing technologies. IET Collab. Intell. Manuf., 2(2), 96-99. https://doi.org/10.1049/iet-cim.2020.0041

Taplin, R. (2013). The influence of competition on visitor satisfaction and loyalty. Tourism Management, 36 (2013), $238-246$. https://doi.org/10.1016/j.tourman.2012.12.012

Tashakkori, A., \& Teddlie, C. (2010). Sage handbook of mixed methods in social \& behavioral research. Sage Publications, California, USA.

Tellioğlu, S. (2020). Kalite Yönetiminde Tedarikçi Yönetimi. "Konaklama İşletmelerinde Kalite Yönetim Uygulamaları: Bütünsel Yaklaşım”" içinde. [In The Quality Management Practices in Hospitality Business: Holistic Approach].181-198, Duman, F., Genç, V. \& Çavuş, F. (ed). Detay Yayıncilık, Ankara, Turkey.

Ţigu, G. \& Calareţu, B. (2013). Supply Chain Management Performance in Tourism, Continental Hotels Chain Case. Amfiteatru Economic Journal, The Bucharest University of Economic Studies, 15(33), 103-115.

Timur, M.N. (2013). Tedarik Zinciri Yönetimi. Timur, M.N. ve Çekerol, G.S., Anadolu Üniversitesi Açık Öğretim Fakültesi Yayını, Eskiş̧ehir, Turkey.

Vatansever, K., \& Tellioğlu, S. (2020). Supplier Selection Using Interval Type-II Fuzzy TOPSIS Method in an Accommodation Company. Ankara Hacı Bayram Veli University Journal of Faculty of Economics and Administrative Sciences, special issue (2020), 133-155.

Wolcott, H.F. (1994). Transforming qualitative data: Description, analysis, and interpretation. Sage Publications, California, USA.

Yıldırım, A., \& Şimşek, H. (2018). Qualitative research methods in the social sciences. Seçkin Yayınc1lı, Ankara, Turkey.

Yin, R. (1984). Case study research: design and methods. (3, edt), Sage Publications, California, USA.

Zambrano-Monserrate, M.A., Ruano, M.A., \& Sanchez-Alcalde, L. (2020). Indirect effects of COVID-19 on the environment. Science of the Total Environment, 728 (2020). 138813. https://doi.org/10.1016/j.scitotenv.2020.138813

Zhang, X., Song, H., \& Huang, G.Q. (2009). Tourism supply chain management: A new research agenda. Tourism Management, 30 (2009), 345-358. https://doi.org/10.1016/j.tourman.2008.12.010

*** ALTSO (2019). Alanya Ekonomik Rapor. [Alanya Economic Report]. Accessed on 02.12.2020. https://www.altso.org.tr/yayinlarimiz/ alanya-ekonomik-rapor/alanya-ekonomik-rapor-2019/

*** Express (2020). Turkey holidays: Destination reveals their 'Safe Tourism Program' for holidaymakers. Accessed on 02.11.2020. https://www.express.co.uk/travel/articles/1309086/Turkey-holidays-2020-flights-abroad-countries-exempt-quarantine-FCO-travel-advice-video

*** Hurriyet (2020). Vacationers are satisfied with 'safe certified' hotels. Accesed on 05.11.2020. https://www.hurriyet.com.tr/seyahat/ tatilciler-guvenli-sertifikali-otellerden-memnun-41558409

*** KTB (2020). Tourism Statistics. Accesed on 28.11.2020. https://yigm.ktb.gov.tr/TR-9851/turizm-istatistikleri.html

*** KTB (2008). Environmental Awareness Campaign (Green Star). Accessed on 31.10.2020. https://yigm.ktb.gov.tr/TR-11596/cevreyeduyarlilik-kampanyasi-yesil-yildiz.html

*** Skift (2020). Hotels Chains Maneuver to Deal with Coronavirus Gut Punch. Accesed on 31.10.2020. https://skift.com/2020/03/18/ hotels-chains-maneuver-to-deal-with-coronavirus-gut-punch/

*** TGA (2020a). Evaluation form for COVID-19 and hygiene practices to be applied during the pandemic for food \& beverage facilities (Accessed on 29.10.2020). https://tga.gov.tr/wp-content/uploads/2020/08/Yemeicme-TR.pdf

*** TGA (2020b). About Turkey's Safe Tourism Certification Program. Accessed on 29.10.2020. https://www.tga.gov.tr/turkiyenin-guvenliturizm-programi-hakkinda/

*** T.C. Resmi Gazete (2017). Environmentally Friendly Accommodation Facilities Evaluation Form. (Accessed on 29.11.2020). https://www.resmigazete.gov.tr/eskiler/2017/06/20170619-8-1.pdf

*** UNWTO (2019). Why Tourism? Accessed on: 01.10.2020. https://www.unwto.org/why-tourism

*** UNWTO (2020). Impact assessment of the covid-19 outbreak on international tourism. Accessed on 25.10.2020. https://www.unwto.org/impact-assessment-of-the-covid-19-outbreak-on-international-tourism

*** World Economic Forum (2020). This is how coronavirus could affect the travel and tourism industry. Accessed on 29.11.2020. https://www.weforum.org/agenda/2020/03/world-travel-coronavirus-covid19-jobs-pandemic-tourism-aviation/

*** USA Today (2020). Marriott to furlough tens of thousands of workers as coronavirus batters hotel industry. Accessed on 01.11.2020. https://www.usatoday.com/story/money/2020/03/17/marriott-furloughs-layoffs-coronavirus-covid-19/5068070002/

Article history: Received: 20.01.2021 Revised: 19.03.2021 Accepted: 05.05.2021 Available online: 27.05.2021 